\title{
Oceanography
}

CITATION

Heesemann, M., T.L. Insua, M. Scherwath, S.K. Juniper, and K. Moran. 2014. Ocean

Networks Canada: From geohazards research laboratories to Smart Ocean Systems.

Oceanography 27(2):151-153, http://dx.doi.org/10.5670/oceanog.2014.50.

DOI

http://dx.doi.org/10.5670/oceanog.2014.50

COPYRIGHT

This article has been published in Oceanography, Volume 27, Number 2, a quarterly journal of The Oceanography Society. Copyright 2014 by The Oceanography Society. All rights reserved.

USAGE

Permission is granted to copy this article for use in teaching and research. Republication, systematic reproduction, or collective redistribution of any portion of this article by photocopy machine, reposting, or other means is permitted only with the approval of The Oceanography Society. Send all correspondence to: info@tos.org or The Oceanography Society, PO Box 1931, Rockville, MD 20849-1931, USA. 


\title{
Ocean Networks Canada
}

\section{From Geohazards Research Laboratories to Smart Ocean Systems}

\author{
BY MARTIN HEESEMANN, TANIA L. INSUA, MARTIN SCHERWATH, S. KIM JUNIPER, AND KATE MORAN
}

Ocean Networks Canada (ONC; http://www.oceannetworks.ca) operates the NEPTUNE and VENUS cabled ocean observatories off the western coast of Canada (Figure 1) and an increasing number of miniature ocean observatories, such as in the Canadian Arctic. These observatories collect data on physical, chemical, biological, and geological properties of the ocean and seafloor over long time periods, supporting research on complex Earth processes in ways not previously possible (Taylor, 2009; Barnes et al., 2012, 2013). All recorded data are permanently archived and publicly available in real time through ONC's Oceans 2.0 data portal. Much of the data collected by ONC is related to marine geohazards, such as earthquakes, tsunamis, submarine landslides, waves, and gas hydrate stability. These real-time data are used by early warning centers and could be made available to decision makers through Smart Ocean Systems (http://www. oceannetworks.ca/technology-services/smart-ocean-systems).
Figure 1. Overview map showing the locations of Ocean Network Canada's NEPTUNE and VENUS cabled ocean observatories. Primary nodes that provide power and Internet to connected junction boxes and instruments are shown as orange squares. The NEPTUNE observatory covers the northern part of the Juan de Fuca Plate and of the Cascadia subduction zone, where the Juan de Fuca Plate subducts beneath the North American Plate. The insets highlight (a) the tsunami meter that is arranged around the Cascadia Basin node, and (b) the Delta Dynamics Laboratory at the mouth of the Fraser River. Bathymetry Data Sources: Saanich Inlet and Strait of Georgia bathymetry from Canadian Hydrographic Service; USCS Cascadia DEM report 99-369; University of Washington (UW), School of Oceanography, R/V Thomas G. Thompson, multibeam cruise data (funding provided by KECK Foundation and UW). Plate Boundaries: Adapted from Dragert et al. Science, May 2001. Map Creation: Center for Environmental Visualization, UW School of Oceanography.

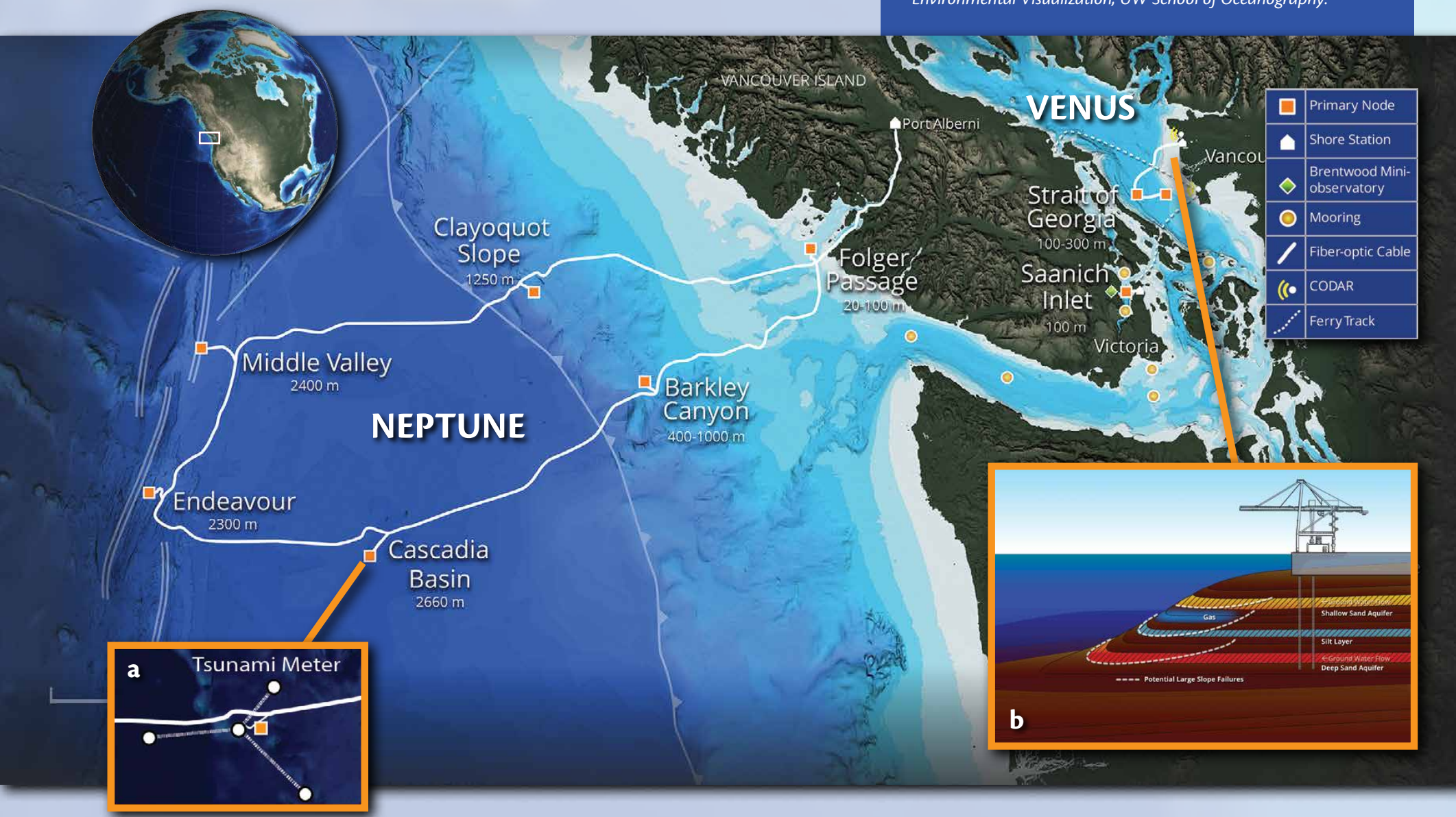


NEPTUNE: AN EARTHQUAKES AND TSUNAMI RESEARCH LABORATORY The NEPTUNE cabled observatory monitors the continental shelf and slope off the west coast of Vancouver Island as well as the complete northern part of the Juan de Fuca Plate. Its cable loop is more than $800 \mathrm{~km}$ long and covers the coastal zone, the northern part of the Cascadia subduction zone, Cascadia Basin, and the Endeavour Segment of the Juan de Fuca Ridge (Figure 1).

Currently, seismometers installed at each of the NEPTUNE nodes (except for the shallow Folger node) are recording relatively little seismic activity on the northern Cascadia subduction zone (Figure 1), consistent with a fully locked seismogenic zone (Scherwath et al., 2011). However, geological evidence suggests a $25-40 \%$ probability of a magnitude 8 or greater megathrust earthquake occurring along the Cascadia subduction zone in the next 50 years (Goldfinger et al., 2012). Sedimentary records of episodic coastal subsidence and offshore turbidites confirm that the interface between the Juan de Fuca and North American Plates has produced numerous great megathrust earthquakes and tsunamis, with an average recurrence interval of about 500 years (Goldfinger, 2011). The most recent great earthquake, with an estimated magnitude of about 9.0, occurred in 1700 and caused widespread tsunami damage in Japan (Atwater et al., 2005).

Most of the tsunamis that arrive along the west coast of North America originate from distant sources around the Pacific (Clague et al., 2003). Over the last 100 years, about 500 major tsunamis have occurred in the Pacific Ocean, killing tens of thousands of people (Lockridge, 1988; Clague et al., 2003), and the probability of a potentially

Martin Heesemann (mheesema@uvic.ca) is Staff Scientist, Tania L. Insua is Ocean Analytics Program Manager, Martin Scherwath is Staff Scientist, S. Kim Juniper is Director, Science \& User Engagement, and Kate Moran is President and Chief Executive Officer, all at Ocean Networks Canada, University of Victoria, Victoria, BC, Canada.

damaging tsunami (runup $\geq 1.5 \mathrm{~m}$ ) for the Canadian outer Pacific coastline is 40-80\% in 50 years (Leonard et al., 2014). To monitor these tsunamis, the NEPTUNE observatory also includes high-precision bottom pressure recorders at each of its nodes and a tsunami meter consisting of three additional bottom pressure recorders arranged on an $\sim 20 \mathrm{~km}$ radius circle around the flat Cascadia basin site (Figure 1). On September 30, 2009, just days after the first instruments were installed, the first tsunami waves of 2.5 to $6 \mathrm{~cm}$ amplitude associated with the transoceanic tsunami generated by the $M_{W} 8.1$ Samoa earthquake in the South Pacific were recorded by six instruments (Thomson et al., 2011). The Samoan tsunami was followed by several other events recorded by the network, including the 2010 Chilean tsunami, the 2011 Tōhoku-Oki earthquake and tsunami (Figure 2), and the 2012 Haida Gwaii tsunami (Fine et al., 2013; Rabinovich et al., 2013a, 2013b; Leonard and Bednarski, 2014). These open ocean observations were uncontaminated by complex bathymetry or coastal reflections, demonstrating that NEPTUNE

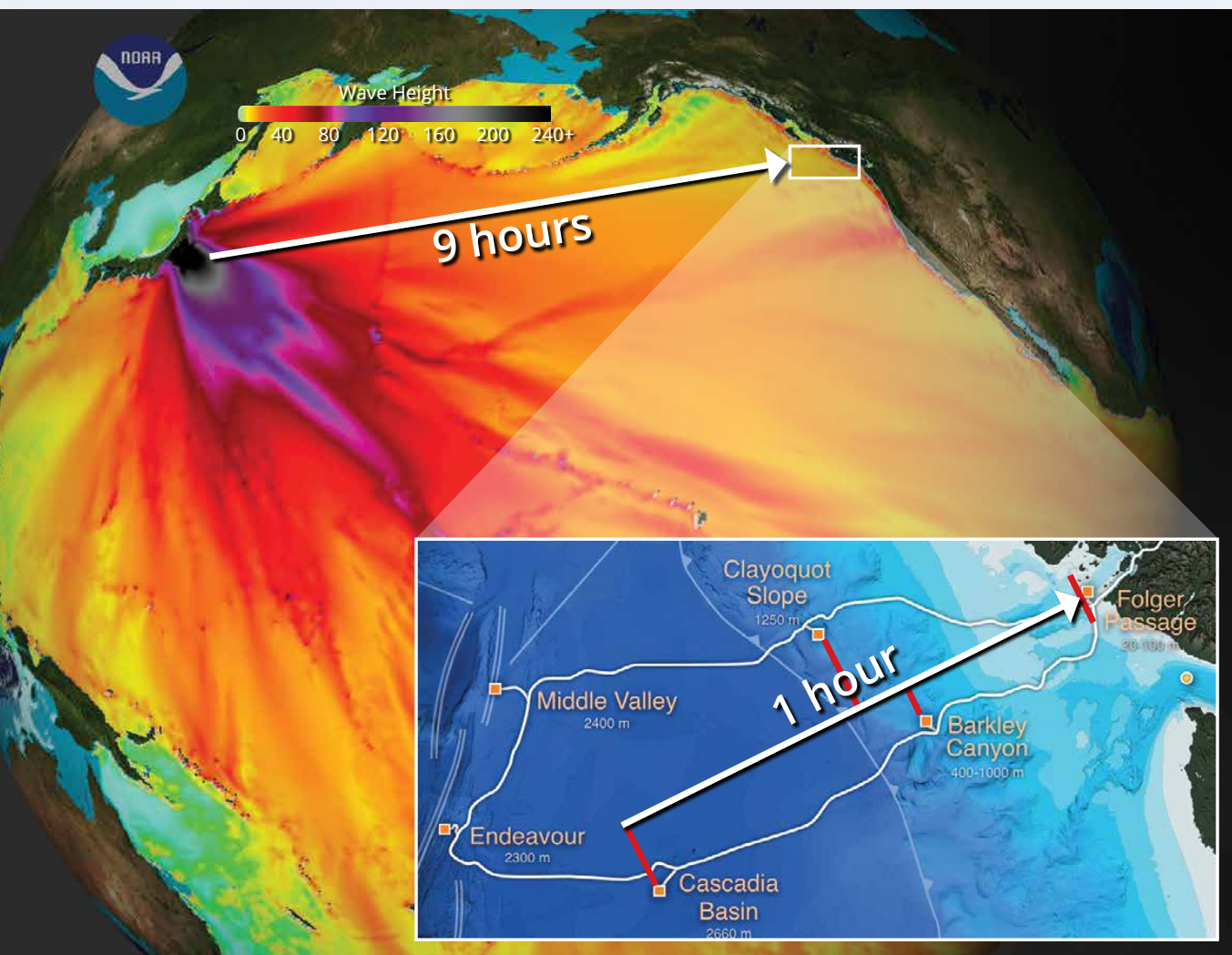

SEAFLOOR PRESSURE

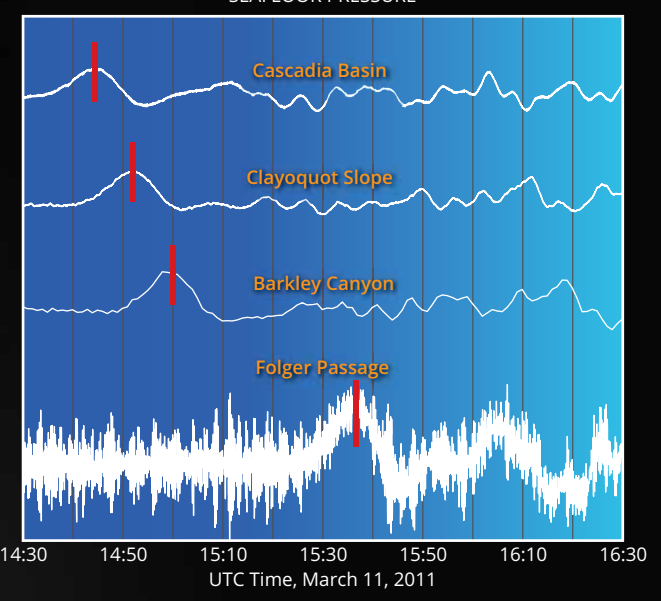

Figure 2. Ocean Networks Canada bottom pressure recorders provide early warning for tsunamis reaching Canada's west coast. The plots show changes in bottom pressure due to tsunami waves generated by the 2011 Töhoku-Oki earthquake off Japan successively crossing different node locations of the NEPTUNE observatory. 
records from future tsunami events can be effectively used as real-time input to regional numerical tsunami forecast models. In fact, real-time data from NEPTUNE seismometers and bottom pressure recorders already feed into the tsunami early warning systems operated by the National Oceanic and Atmospheric Administration (NOAA) Pacific and West Coast and Alaska Tsunami Warning Centers.

\section{VENUS: AN UNDERWATER LANDSLIDE RESEARCH LABORATORY}

An important purpose of the VENUS cabled observatory is monitoring the Fraser River delta's main channel off of Vancouver, BC (Figure 1). With a peak discharge of nearly 10,000 cubic meters of silt-laden water per second in May and June, sediments rapidly accumulate in the Fraser River delta, often resulting in unstable slopes that can fail catastrophically as underwater landslides. Because the delta is located near important coastal infrastructure including the Vancouver Airport, the deep-sea Deltaport container terminal, and the Tsawwassen ferry terminal, it is critical to gain a proper understanding of this dynamic coastal region.

One type of instrument currently deployed on the VENUS Observatory to monitor slope stability-known as a Seismic Liquefaction In Situ Penetrometer-uses piezometers (to measure pressure in the water column and seabed), accelerometers (to measure seismic activity), and inclinometers (to measure sediment movement through strain) to gather data on the conditions associated with slope failure. Another instrument package, the Delta Dynamics Laboratory, provides additional environmental information concerning water properties, turbidity, and currents for the slope stability studies. Additionally, hydrophones are installed to listen for undersea landslides and earthquakes (Lintern and Hill, 2010).

\section{SMART OCEAN SYSTEMS}

Ocean Networks Canada actively pursues opportunities to make sure that its extensive research observatories provide socioeconomic benefits. For instance, the new
Smart Oceans BC program (http://www. oceannetworks.ca/about-smart-oceans-bc) aims to provide online and real-time management portals to industry, government, First Nations, and local stakeholders for preventing accidents, responding to situations as they arise, forecast and warning of natural hazards, and supporting overall marine operational situational awareness.

\section{ACKNOWLEDGEMENTS}

Ocean Networks Canada, an initiative of the University of Victoria, was developed through a consortium of 12 Canadian universities, government laboratories, and international institutions. The major funders include the Government of Canada, the Canada Foundation for Innovation, the Government of British Columbia, the Natural Sciences and Engineering Research Council of Canada, Western Economic Diversification Canada, Canada's Advanced Research and Innovation Network, and the National Centres of Excellence. We thank Garry Rogers, Robert Meldrum, Gwyn Lintern and Earl Davis from the Geological Survey of Canada and Richard Thomson from the Department of Fisheries and Oceans, who among many others, played leading roles in the design, implementation and operation of ONC's geohazards research laboratories.

\section{REFERENCES}

Atwater, B.F., M.-R. Satoko, S. Kenji, T. Yoshinobu, U. Kazue, and D.K. Yamaguchi. 2005. The Orphan Tsunami of 1700: Japanese Clues to a Parent Earthquake in North America. US Geological Survey Professional Paper 1707, University of Washington Press, 144 pp, http://pubs.usgs.gov/pp/pp1707.

Barnes, C.R., M.M.R. Best, F.R. Johnson, L. Pautet, and B. Pirenne. 2013. Challenges, benefits, and opportunities in installing and operating cabled ocean observatories: Perspectives from NEPTUNE Canada. IEEE Journal of Oceanic Engineering 38:144-157, http://dx.doi.org/10.1109/JOE.2012.2212751.

Barnes, C.R., M.M.R. Best, P. Johnson, F.R. Phibbs, and B. Pirenne. 2012. The NEPTUNE Canada Project: Installing the world's first regional cabled ocean observatory. Chapter 16 in Seafloor Observatories: A New Vision of the Earth from the Abyss. P. Favali, L. Beranzoli, and A. de Santis, eds, Geophysical Sciences, Springer.

Clague, J.J., A. Munro, and T.S. Murty. 2003. Tsunami hazard and risk in Canada. Natural Hazards 28:433-461, http://dx.doi.org/10.1023/A:1022994411319.
Dragert, H., K. Want, and T.S. James. 2001. A silent slip event on the deeper Cascadia subduction interface. Science 292:1,525-1,528, http://dx.doi.org/10.1126/ science. 1060152.

Fine, I.V., E.A. Kulikov, and J.Y. Cherniawsky. 2013. Japan's 2011 tsunami: Characteristics of wave propagation from observations and numerical modelling. Pure and Applied Geophysics 170:1,295-1,307, http://dx.doi.org/10.1007/s00024-012-0555-8.

Goldfinger, C. 2011. Submarine paleoseismology based on turbidite records. Annual Review of Marine Science 3:35-66, http://dx.doi.org/10.1146/ annurev-marine-120709-142852.

Goldfinger, C., C.H. Nelson, A.E. Morey, J.E. Johnson, J.R. Patton, E. Karabanov, J. Gutiérrez-Pastor, A.T. Eriksson, E. Gràcia, G. Dunhill, and others. 2012. Turbidite Event History: Methods and Implications for Holocene Paleoseismicity of the Cascadia Subduction Zone. US Geological Survey Professional Paper 1661-F, 170 pp., http://pubs.usgs.gov/pp/pp1661f.

Leonard, L., and J. Bednarski. 2014. Field survey following the 28 October 2012 Haida Gwaii tsunami. Pure and Applied Geophysics, http://dx.doi.org/10.1007/ s00024-014-0792-0.

Leonard, L., G. Rogers, and S. Mazzotti. 2014. Tsunami hazard assessment of Canada. Natural Hazards 70:237-274, http://dx.doi.org/10.1007/ s11069-013-0809-5.

Lintern, D.G., and P.R. Hill. 2010. An underwater laboratory at the Fraser River delta. Eos Transactions, American Geophysical Union 91:333-334, http://dx.doi.org/10.1029/2010EO380001.

Lockridge, P.A. 1988. Historical tsunamis in the Pacific basin. Pp. 171-181 in Proceedings of the International Symposium on Natural and Man-Made Hazards. M.I. El-Sabh and T.S. Murty, eds, Springer.

Rabinovich, A.B., R.N. Candella, and R.E. Thomson. 2013a. The open ocean energy decay of three recent trans-Pacific tsunamis. Geophysical Research Letters 40:3,157-3,162, http://dx.doi.org/10.1002/ grl.50625.

Rabinovich, A.B., R.E. Thomson, and I.V. Fine. 2013b. The 2010 Chilean tsunami off the west coast of Canada and the northwest coast of the United States. Pure and Applied Geophysics 170:1,529-1,565, http://dx.doi.org/10.1007/s00024-012-0541-1.

Scherwath, M., G. Spence, K. Obana, S. Kodaira, K. Wang, M. Riedel, J. McGuire, and J. Collins. 2011. Seafloor seismometers monitor northern Cascadia earthquakes. Eos Transactions, American Geophysical Union 92:421-422, http://dx.doi.org/ 10.1029/2011EO470001.

Taylor, S.M. 2009. Transformative ocean science through the VENUS and NEPTUNE Canada ocean observing systems. Nuclear Instruments and Methods in Physics Research Section A: Accelerators, Spectrometers, Detectors and Associated Equipment 602(1):63-67. Proceedings of the 3rd International Workshop on a Very Large Volume Neutrino Telescope for the Mediterranean Sea, G. Hallewell, S. Bradbury, P. Coyle, S. Henry, A. Kappes, P. Kooijman, P. Piattelli, and M. Taiutti, eds, http://dx.doi.org/10.1016/ j.nima.2008.12.019.

Thomson, R., I. Fine, A. Rabinovich, S. Mihály, E. Davis, M. Heesemann, and M. Krassovski. 2011. Observation of the 2009 Samoa tsunami by the NEPTUNE-Canada cabled observatory: Test data for an operational regional tsunami forecast model. Geophysical Research Letters 38, L11701, http://dx.doi.org/ 10.1029/2011GL046728. 